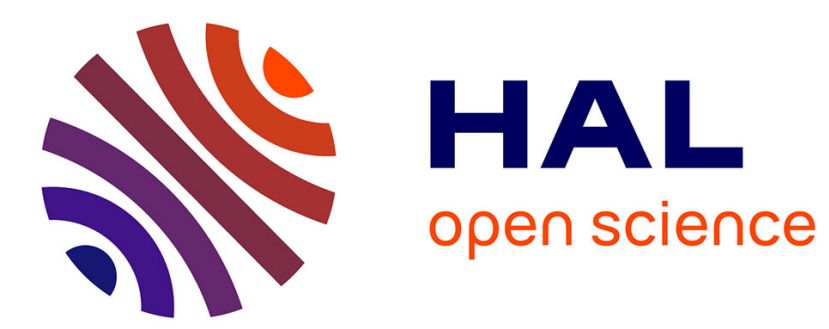

\title{
Tannese Chiefs, State Structures, and Global Connections in Vanuatu \\ Marc Tabani
}

\section{To cite this version:}

Marc Tabani. Tannese Chiefs, State Structures, and Global Connections in Vanuatu. Contemporary Pacific, 2019, 31 (1), pp.65-103. 10.1353/cp.2019.0006 . hal-02178789

\section{HAL Id: hal-02178789 \\ https://hal.science/hal-02178789}

Submitted on 28 Dec 2021

HAL is a multi-disciplinary open access archive for the deposit and dissemination of scientific research documents, whether they are published or not. The documents may come from teaching and research institutions in France or abroad, or from public or private research centers.
L'archive ouverte pluridisciplinaire HAL, est destinée au dépôt et à la diffusion de documents scientifiques de niveau recherche, publiés ou non, émanant des établissements d'enseignement et de recherche français ou étrangers, des laboratoires publics ou privés. 


\section{Tannese Chiefs, State Structures, and Global Connections in Vanuatu}

Marc Tabani

In Vanuatu, at the beginning of the independence process in the I970s, referring insistently and positively to the concept of kastom in public discourses emerged as a notable feature of political rhetoric. For anyone engaged in the European style of political debate, referring to kastom became a well-established practice verging on obligatory. The symbolic efficacy of the word seems to rest in its capacity to summon into view and claim a political unity based on belonging to a shared cultural community rooted in a timeless incontestable past. However, the growing frequency of these rhetorical expressions of kastom is far from timeless. Indeed, one can trace historical attempts at politicizing the meaning of this word to make it coincide with contemporary ideological and political ideals (Keesing and Tonkinson 1982; Lindstrom and White 1993). Kastom took on a nationalist and traditionalist emphasis to epitomize a shared abstract cultural value in which the strategic process of nation-building could be anchored. When kastom in Vanuatu began to be incorporated in the conception, constitution, and practices of the state (Miles I998), its meaning began to encompass both " 'traditional traditions' and 'traditionalist traditions"” (Otto and Pedersen 2005) and to serve as a cultural as well as a political tool (Akin 2004; Babadzan 2004). In the postcolonial intensification of "kastomization" in national politics in Vanuatu (Lindstrom 1997)—that is, of making the state "kastom friendly" and vice versa-certain underlying symbols such as jifs (chiefs), nakamal (traditional meeting places), and kava became central to the dynamics playing an active role in the (re) valuation and transformation of the term.

According to a state-centered or constitutional version of kastom, traditional political practices in Vanuatu are legally meant to be personified by jifs. Such an official claim has helped to strengthen a popular view of

The Contemporary Pacific, Volume 31, Number I, 65-103

(C) 2019 by University of Hawai $i$ Press 
these authority figures as consubstantial with kastom (Bolton I998). Since then, a if has no longer been just a traditional leader for his community, but also "an icon of local tradition and identity" (White and Lindstrom I 997, I). The nakamal is thus generally considered as a place where $j$ ifs exercise their authority and demonstrate their powers. In this dedicated space, their ability to maintain peace and unity can be further consolidated by the drinking of kava, for instance as a mandatory feature or protocol for the closing ceremony of any public gathering. Whether these notions have English or vernacular etymologies, their extensive use is consecutive to recent semantic standardizations introduced to fit present social and political realities both at local and national levels. This "semantic function" plays a key role in the dynamics of traditionalism. According to Georges Balandier, "Political structures resulting from the establishment of the 'new states' can be interpreted, during the transitional period, only in the terms of the old language. These structures can command neither immediate comprehension nor immediate support from traditional peasantries" (I970, I75).

However, the seemingly stable or ancient political terms or concepts in many Oceanic languages may be sometimes less old than is generally thought (Vernaudon, Bambridge, and Sam 20II). Thus, none of the vernacular terminologies related to power and hierarchy in the Austronesian languages of Vanuatu precisely expressed the classic sociological definitions of "chief" - the main authority in the monopoly on the legitimate use of violence in traditional social orders: "There are no chiefs in NiVanuatu custom, except in a few, specific areas. There are only big men and the English word 'chief' has had to be incorporated into many NiVanuatu languages to refer to the most influential man in a village" (MacClancy I980, 77).

This article concentrates on several aspects of the ongoing transformation of traditional leadership in postcolonial Vanuatu. It provides updates on recent changes in the political role of contemporary "chiefs" and other leaders and in their relations with state bureaucracies. Finally, it examines these dynamics in the specific context of Tannese society, in the south of the archipelago. Although Tanna is currently seen by many Ni-Vanuatu as still deeply respectful of kastom rules in everyday life, its inhabitants have always experimented a great deal in chiefly matters. To put it in another way, indigenous traditions relating to the exercise of power and to expressions of authority have never been static and are among those that have significantly changed. Marshall Sahlins, for instance, has identified tradi- 
tional leaders in the Pacific with the most flexible and durable part of tradition, placing them at the vanguard of the "indigenization of modernity" process. The "most powerful chiefs" and the "biggest big men," he noted, all came into existence after early European presence, not before (Sahlins I992, I 7). ${ }^{1}$ More recently, archeological findings have even suggested that big men in Melanesia are a creation entirely due to post-Western contact influences and that they were born out of the decline of formerly more powerful authority figures who ruled over less egalitarian societies (Spriggs 2008; see also Sand 2002). Bigmanship would thus appear to have been an indigenous politico-economic response to drastic social changes, characterized by huge demographic collapse and the consequences of colonial pacification.

Insofar as traditional political leaders are commonly considered to be embodiments of kastom, this focuses on their propensity for mediating and, at times, transforming the collective relationship to tradition, while also transforming their own role. If the loss of respect for chiefs is frequently ranked as the main symptom of the decline of kastom, the nonrespectful attitudes of these leaders toward the very source of their legitimacy is seen as its foremost cause. However, Christianization, colonial control, community development, national unity, and democratizationall successive outside sources of interference with indigenous systems of authority-have usually been concerned more with the evolving role of chiefs than with other changing aspects of local kastom. The informative case of Tanna's contemporary "chiefs" supports the argument that although they have emerged from the island's changing political landscape through local agency, they have at the same time been dealing with a host of miscellaneous outsiders and foreign resources (Guiart I956; Adams I984; Bonnemaison I987). The way they are simultaneously framed by the local and the global is observed here through the modernization of traditional processes in which they are increasingly involved (Lindstrom I990; Bolton I998).

A short overview of the historical emergence and national cultural constructions of chiefs in Vanuatu should help us to examine how the dialectic of simultaneously politicizing and depoliticizing chiefs has been transferred by the central state to rural contexts. Identifying kastom jifs-that is, including or excluding different sorts of leaders from this category-has remained a widespread practice. The use, or sometimes abuse, of kastom titles for personal interest fuels recurrent disputes over cultural property and cultural appropriation. But on the other hand, exploiting kastom titles 
for nontraditional purposes offers new possibilities for a better state and wider global connections, even with outsiders interfering in island politics. Among different aspects of selecting chiefs, special attention is given in this article to procedures that follow an entirely non-customary process, like the creation of councils, elections, or dubious co-options. Here again Tanna provides an interesting case study of the repeated attempts that have been made by rival chiefly institutions to codify kastom, while at the same time ensuring the conversion of their ancient privileges into new bureaucratic attributions.

In their new role as tenured "masters of tradition," customary chiefs today in Tanna, like elsewhere in Vanuatu (Rodman I987), have to manage ever-increasing connections with faraway actors and distant places. Over the last twenty years, the political history of Tanna has provided many examples of how traditional leaders have treated kastom as a political and economic resource on a global scale, accepting a strategy that is not without risk for the stability of their own local communities.

\section{Chiefs, Kastom Titles, and State Structures in Vanuatu}

The Condominium of the New Hebrides, first set up in I906, was mocked as a "pandemonium" due to its inefficient bureaucracy and administrative gridlock. It was a double-headed colonial territory where the French and British, despite their historical "entente cordiale" declaration, constantly agreed to disagree. They also diverged in their respective views of what chiefs, as an institution, were or should become. Indeed, given this context, it is not easy to clearly define whether this archipelago should be considered as having been governed under direct or indirect rule. The $\mathrm{Ni}$ Vanuatu, as noncitizens without any civic rights, remained under the rule of custom or the Church during most of the colonial period, but not necessarily under the law of "traditional chiefs" (Hours I978). In comparison to priests, colonial officers, or indigenous assessors, village chiefs appear to have had little effective power and may have been merely the brokers of colonial times, "individuals selected to represent the community in nontraditional contexts" (Bolton I998, I 85 ).

This situation definitively changed in 1975 , when the pro-independence New Hebrides National Party won the first general election for a Representative Assembly. But its majority could have been endangered by the complementary election to this assembly of four chiefs by an electoral col- 
lege composed of their fellow "customary chiefs" from the four administrative districts. This strategy was not without consequences: "The Condominium wished to include kastom jifs in the Representative Assembly but the variability of customs from island to island, plus the decay or change in traditional political organization in many areas made the definition of who was, or was not, a kastom jif highly problematic" (MacClancy I988, I04). From September I975 to June I976, the election of these chiefs was at the center of New Hebrides political life: "The two governments, ... each with their own vision of custom, interfered a lot with the election without any legitimacy. Elected members were refused by District Agents for a lack of valid customary genealogy or on other such pretexts" (Hours I978, I 8). But after this initial foreign intervention in the process of selecting chiefs, the politicization of kastom took on its full dimension with the creation of a special category of selected individuals meant to embody it. Formalizing jifs as a kastom elite gave them an importance beyond the local level and created a potential social ranking that had not existed formerly: "This new role for chiefs as representing kastom significantly, and subtly, underlines the identification of chiefs as traditional leaders-not as a matter of European perception, but of local practice. As a consequence, the relationship of chiefs to the traditional sources of authority they were now to represent became much more crucial and was disputed at a local level" (Bolton I998, I85-I86).

Henceforth, the legitimacy of chiefs and the institutional role they would or would not have to play in relation to the sovereign state and the nation-building process produced heated debates about "what was true kastom and what was gammon [ie, nonsense]" (MacClancy I980, 78). To be accused of being a "politikol jif" became a reversible criticism. It was a derogatory argument made use of by both pro-nationalist Christian chiefs and anti-state control traditionalist chiefs. Many criticized each other in order to claim and manipulate kastom in their own interest instead of that of the people they were supposed to represent. In certain circumstances, these antagonisms have persisted: “Today's kastom iifs, although undoubtedly kastom, are not simply customary" (Lindstrom I997, 212). The quest to identify iifs strictly legitimated by kastom continues. Most $\mathrm{Ni}$-Vanuatu at least agree that some kastom jifs appear less customary than others; many could also approve the definition of the three categories of chiefs given by Jean-Marie Léyé, the first president of the Republic of Vanuatu: 
["Political chiefs"] had achieved positions of leadership through their activity in politics. ["Missionary chiefs"] had been risen to the position of chiefs by the missionaries. [The "Land chiefs"] were the genuine custom chiefs. (Constitutional Committee 2009, I40)

But even for leaders of the third category, ambiguities remain concerning the relations of chiefs to the state. As middlemen, they serve the state and are served by it, but they can also tread on it as they tread on and betray their own people when they fail to respect the spirit of kastom in their deeds (Lindstrom I997). This is one of the reasons why, even when chiefs are considered in a nationalist perspective as a powerful symbol of sovereignty, they can represent neither the whole of customary hierarchy nor the whole of kastom as a foundation of national identity: "Chiefs are but one fiber of the cloth of kastom" (Miles I993, 37). But chiefly titles are still needed for politicians and charismatic leaders to gain power. Postcolonial leaders have played an eminent role in turning local customary titles into state kastom protocol (see Tabani 2002).

But showing empathy for kastom by claiming a customary name or title, or both, would henceforth seem even more futile when it concerned naturalized citizens or even foreigners trying to achieve personal political or business objectives. The media frequently mention cases of such foreigners having locally received a chiefly title. Ofer Shagan, an Israeli citizen and renowned art dealer in Tokyo who had bought land in Vanuatu for tourism developments, was adopted in Tautu (Malekula), where he received from the local community the chiefly title Apia Nemt Enuanu (the Eyes of the Chiefs) (Japan Times, I 8 Dec 2005). His customary appointment was only contested on the grounds that he also claimed in the international press that he was henceforth "king of Malekula" (Vanuatu Daily Post, I7 March 2006). Dominique Dinh, a local businessman and son of an indentured laborer, received the chiefly names Tamakaro and Lapangtaua after having been adopted both in Pango and Tanna. He then created the "Chiefs' Movement of Vanuatu" and was appointed "chief of chiefs." His profile is very similar to that of his brother, the very wealthy entrepreneur Gilbert Dinh Van Than, the "largest private employer in Vanuatu and, many say, the most politically influential and controversial citizen" (Crocombe 2007,76 ). Last but not least, their sister Thi Tam Goiset later also became involved in customary politics. With a name bestowed in 2008 in Vanafo (Santo)-Te Moli Venaos Mol Saken-and two more in 2009 
in Tanna-Nanumian and Swerenao-she was proclaimed "paramount chief" of two former secessionist indigenous movements, Nagriamel and John Frum, a position intended to give her more credit when in 20I I the Vanuatu government appointed her roving ambassador to Russia.

This matter of kastom if titles held by outsiders would appear to be one of the least traditional practices. Nevertheless, it has so far engendered fewer disturbances at the grassroots level than the contamination of local community leaders by national politics. Through the institutionalization of neotraditional authorities and the bureaucratic attributions conferred on them, some of these leaders turned into kastom-ideology activists and tried to take advantage of their newly fashioned "state jif" role (Lindstrom I997). This radical innovation came into being with the creation of the National Council of Chiefs, also called the Malvatumauri, after independence. In I975, the French administration tried to oppose the election of two pro-independence leaders among the four custom chiefs meant to join the first Representative Assembly. The pro-French party Union des Communautés des Nouvelles-Hébrides recommended adding five more seats in the assembly for chiefly representatives. Finally, at the end of June I976, agreement was achieved that twenty more chiefs (five from each district) would be independently elected, in addition to the vote by universal suffrage, to form a separate "Council of Chiefs." The election of I 4 pro-independence chiefs out of a total of 24 definitively overcame pro-French attempts to use traditionalist forces in order to challenge the growing majority of nationalist supporters. Among those who had been elected, some were "traditional custom chiefs wearing customary dress who were very often skeptical of politics, or disappointed with it, as well as politically involved men such as priests or non-traditional leaders" (Hours I978, I9). The legitimacy of the Malvatumauri was confirmed at independence by the first elected government. A National Day of Chiefs, every $5^{\text {th }}$ of May, was validated by the constitution, but any claim to make the Malvatumauri play the role of an upper legislative chamber or Senate was rejected.

The new sovereign state was thus successful in neutralizing this institution's subversive potential and, up until now, its role has remained mostly consultative and symbolic. Chiefs are regularly summoned by politicians who, in order to endorse a series of conservative measures, try to use them in the guise of serving a traditionalist agenda. Placed under the legislative responsibility of the Vanuatu Parliament, the capacities of the Malva- 
tumauri have been restricted to simply advising and making superficial codifications concerning general principles supposed to regulate the realm of kastom.

At a national level, the Malvatumauri has never attempted to define precisely who in Vanuatu can legitimately claim to be a kastom jif. ${ }^{2}$ This institutional task has been relegated to the local politics of each island community. I therefore pursue this survey of noncustomary aspects of chiefly claims and positions by examining the process of codification of kastom at an island level, in a rural context. The case of the island of Tanna provides a good example of the local priority given to the definition of titles, statuses, and capacities that justify the claim to hold a chiefly position and to become part of local councils with other representatives of the same rank.

\section{Precolonial Authorities in Tanna}

Since the Tannese encounter with Captain James Cook in I774, and until the end of the colonial period, all the ethnographic records converge toward a shared statement of fact: "chief" figures did not exist as such in late precolonial Tannese society. In their observations, early European visitors, missionaries, and anthropologists all expressed surprise at this absence. According to reports of the first outsider observers in the eighteenth and nineteenth centuries, the Tannese may have known of the existence of chiefs, given that many of them appeared to hold exclusive hereditary titles. However, none of these titleholders was able to show any authority over other men. No "real" leader was in command: "No Thakombau, Pomare, Kamehameha there" (Turner I86I, 84). Ron Adams provided a short compilation of Europeans' desperate quest to find Pacific high chiefs, ariki, or kings in Tanna:

Cook noted that, [the Tannese who] "have been pointed out to us by that [chief] title ... seemed to have very little authority over the rest of the people." John Reinhold Forster, naturalist on board . . . wrote that chiefs of Tanna were not generally distinguishable from their subjects "by rank or authority, and seem to enjoy only an hereditary title." [As stated by the missionary George Turner, the chief's] authority did not extend beyond "a gunshot from his dwelling.” .. . [Missionary John G] Paton gave up any attempt at consistency, claiming that chiefs on Tanna have really no power. ... [Missionary William Watt's] wife had noted "chieftainship may be said to consist only in name. In a village of eight or nine men, six will claim to be chiefs.” (Adams I984, I4-I 5) 
Clarence B Humphreys speculated that the Tannese may have had powerful "suzerain chiefs" in former times but that due to foreign influence these had suffered a considerable loss of power; in some parts of the island, he surmised, this break with precolonial forms of authority may have been so deep that people completely forgot them (I926). This absence may have undermined foreigners' usual strategies of co-opting local authority figures in order to establish colonial rule over indigenous subjects.

At the end of the nineteenth century, Tanna was placed under an oppressive theocratic missionary regime. The then so-called Tanna law was supported by converted leaders who, in exchange for their support of the radically anti-kastom Presbyterian policy-a programmed cultural tabula rasa-were considered paramount "Christian chiefs" by the mission. Until the establishment of the condominium, these converted leaders worked to repress all symbols of former attributes of hierarchy and traditional power still held by opposing pagan groups. The new hierarchy imposed by the mission was confirmed in the I9IOs with the establishment of an administrative hierarchy based on indigenous district assessors under the rule of district agents. The imposition of the condominium rule created a great deal of anarchy, while reducing the political landscape to single village chiefs without any prerogative other than that of simply being "headmen" of small residential groups. To prevent unrest at the island level, colonial district agents assumed sole control of coercive legal measures. Indirect rule was hence quite limited. The formalization of these new authority figures was accompanied by a standardization of imported titles. Christian chiefs were recruited by the missionaries among elders, pastors, or teachers; administrative village chiefs, called "boss" in Bislama, were employed locally as middlemen, along with indigenous district assessors appointed by French and British colonial officers, and placed under their strict command. Some of these new leaders held simultaneously the attributes of both Christian and administrative chiefs, while sometimes also claiming distinguished, traditionally inherited titles. They are sometimes remembered by older informants as "big jifs." Despite repeated colonial attempts at "chieftainization" of Tannese society, Europeans still faced the greatest difficulties in understanding totally different cultural conceptions of power and hierarchy.

Indeed, after one hundred fifty years of cultural changes, Jean Guiart's field research revealed that the traditional system of acknowledging dignitaries and inheriting special titles and names was not dead at all, even if its coercive efficiency had become largely subaltern to colonial authori- 
ties (1956). He described the Tannese society as one of the most atomistic of Pacific Island cultures. In the I950s, half the members of the male population held a hierarchical position or some privilege legitimated by a complex semi-hereditary titles system. "Some villages or territorial groups have up to twelve chiefs; others have none. At first glance, one may have doubts about the classic description of a Melanesian village chief applying here. ... [There's] a practical impossibility of defining allegiances. It is not known who obeys whom" (Guiart 1956,9 ). A consequence arising from this situation was the "generalization of a science of protocol that would make the herald of a Polynesian court jealous" (Guiart 1956, I07). For a tribal society, Guiart argued, the social organization in Tanna offered the paradoxical image of a "reign of individualism" (I956, I I 5). Whenever their power was actively contested, chiefs were finally created by the combined efforts of missionary and colonial authorities. They coexisted, in a flexible, contextual manner, with former traditional authorities (agrarian specialists, ritual experts, and other owners of renowned titles); new prophetic indigenous leaders; and imported bureaucratic and business authorities. But it was only with the independence of Vanuatu that this process of chief making became really intensive and more efficient. As Julia Wilkinson noted, still at the end of the I970s in Tanna: "The concept of kastom jif was ambiguous and hard to understand. People did not know whether it meant someone who was traditionally a chief as on Tanna, or simply someone who could represent kastom since he still lived in a traditional way and could make sure that new legislation and modernization did not destroy kastom" (I979, I42).

\section{Kastom Titles with Virtual Powers}

The ancient titles system has been somewhat confused by early foreign observers of power relations in Tanna. An incredible multiplicity and diversity of titles hardly seems to fit with a reliable political organization. No two, even when similar, can ever be considered equivalent. Each one is specific and has its own local and particular traditional legitimacy. Although men need titles to maintain inherited privileges or gain hierarchical influence, these remain insufficient. Speaking about titles (a word that does not exist in any of the Tannese languages-such as Kwamera, Whitesands, Southwest Tanna, Lenakel, North Tanna) is itself a way of rationalizing the exercise of power. First and foremost, titles are related to names. Every lineage-like residential group (nemwipwi) possesses a stock 
of ancestral names or "name sets," which are individually passed down from generation to generation through inheritance or adoption. A complete set of names corresponds to all the land that can be claimed by the social group to which names and land belongs. Some holders of the prestigious names part of this stock are chosen within the nemwipwi (sometimes among adopted members) for their personal capacities as much as in accordance with their inherited rights. They can thus benefit from different kinds of contextual privileges at different ceremonial occasions or ritual exchanges. But such temporary and contextual hierarchical distinctions cannot be interpreted in terms of strictly secular power. Names, to be powerful, must be connected to various supernatural capacities related to the use of all sorts of ancestral power stones (nukwei nari) that control the weather, cultigens, pigs' fertility, and the like (figure I). The names of these stones themselves belong to the exclusive corpus of a nemwipwi. More precisely, a nemwipwi's stock of names comes from these ancestral power stones, which represent the original ancestors of each group.

For early missionaries, as well as later for colonial district agents, this names-titles-stones-ancestors system was not considered appropriate for political use. Instead, they engaged in an active struggle against the use of nukwei nari, especially those fearsome sorcery stones that can kill victims (nukwei nahak). A consequence of this rejection was that all the other interconnected aspects of names, stones, and titles were also done away with or greatly displaced. Spiritual powers related to the pagan "Time of Darkness" were not considered a manipulable authority, useful in taking advantage of the Tannese. Nabak stones and the men associated with them were immediately identified as priority targets for elimination:

The real gods at Tanna may be said to be the disease-makers. It is surprising how these men are dreaded, and how firm the belief is that they have in their hands the power of life and death. There are rain-makers and thunder-makers, and fly and mosquito-makers, and a host of other "sacred men," but the disease-makers are the most dreaded. (Turner I86I, 89)

It was not until the I950s that the island had started to recover from several decades of severe depopulation, especially from introduced diseases (Guiart I956, II9). A direct consequence of this demographic upsurge was the widely shared desire to revive titles among groups that no longer had enough men alive to hold them. In these circumstances, many titles were transferred between groups. Many power stones were also destroyed by Christian converts and the use of nabak stones was abolished. 


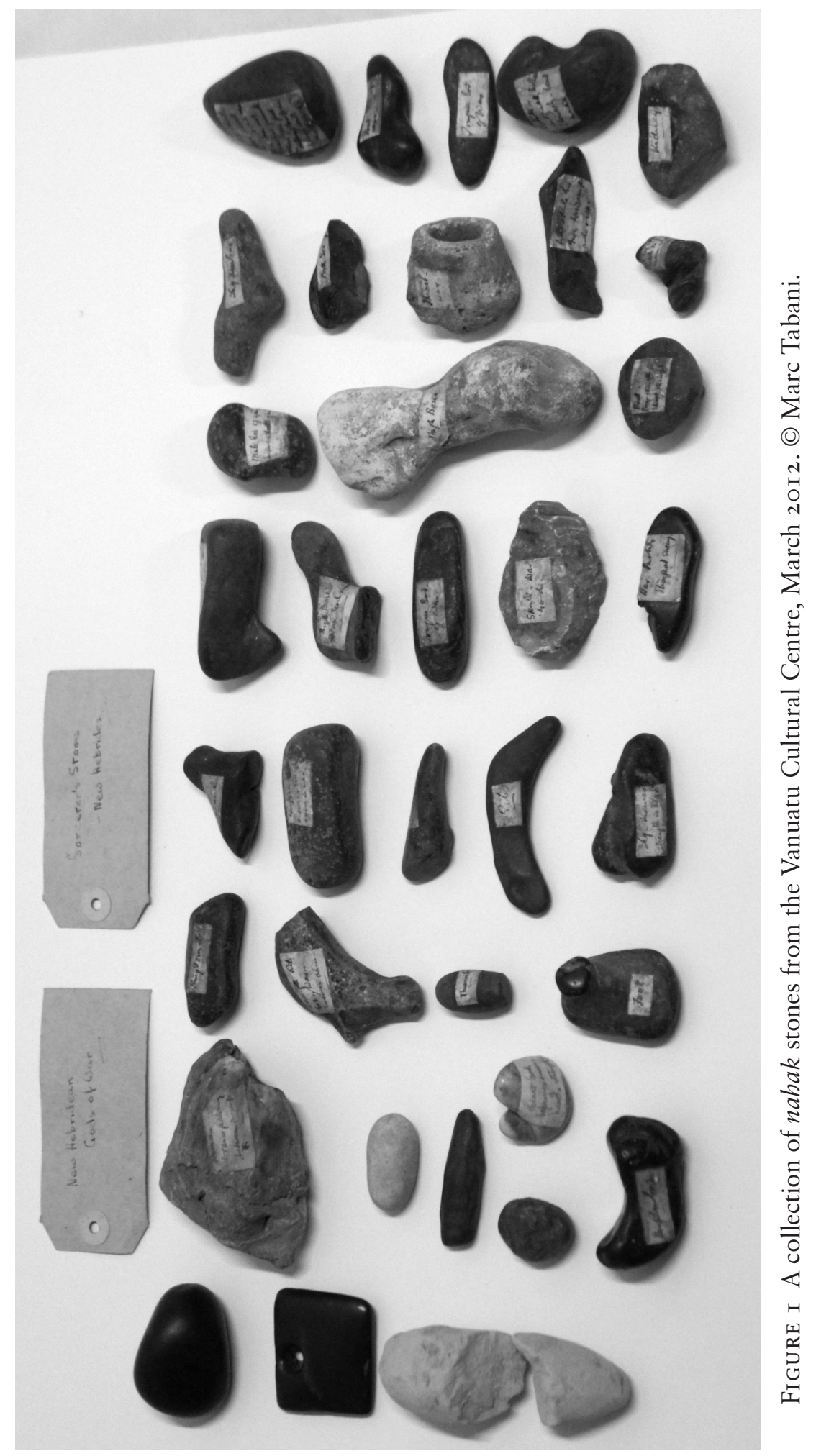


Nevertheless, Guiart succeeded in providing a large list of ritual privileges and ceremonial exchange prerogatives associated with the possession of names, titles, and stones (I956). He also described more precisely how, in that system, certain titles can correspond to specific statuses that enable their holders to play a dominant role in exclusive contexts. Iermenu and ieni neteta are specific statuses or positions that can facilitate the expression of concrete and sometimes enduring leadership. ${ }^{3}$ These are the only titles to which the Tannese are referring when they use the word if today.

In the ritual context of the spectacular nakwiari ceremonies, the iermenu are responsible for the exchanging of hundreds of pigs and as many huge kava roots. ${ }^{4}$ On this occasion, they also publicly exhibit their ritual status by demonstrating their exclusive rights to hold the kwerrya, a giant bamboo pole covered with painted feathers (figure 2). Men of different allied groups, who come to help the iermenu in this honorific task, thus show their commitment to supporting this ritual dignitary in his ceremonial responsibilities and to protecting him in the event of war. This form

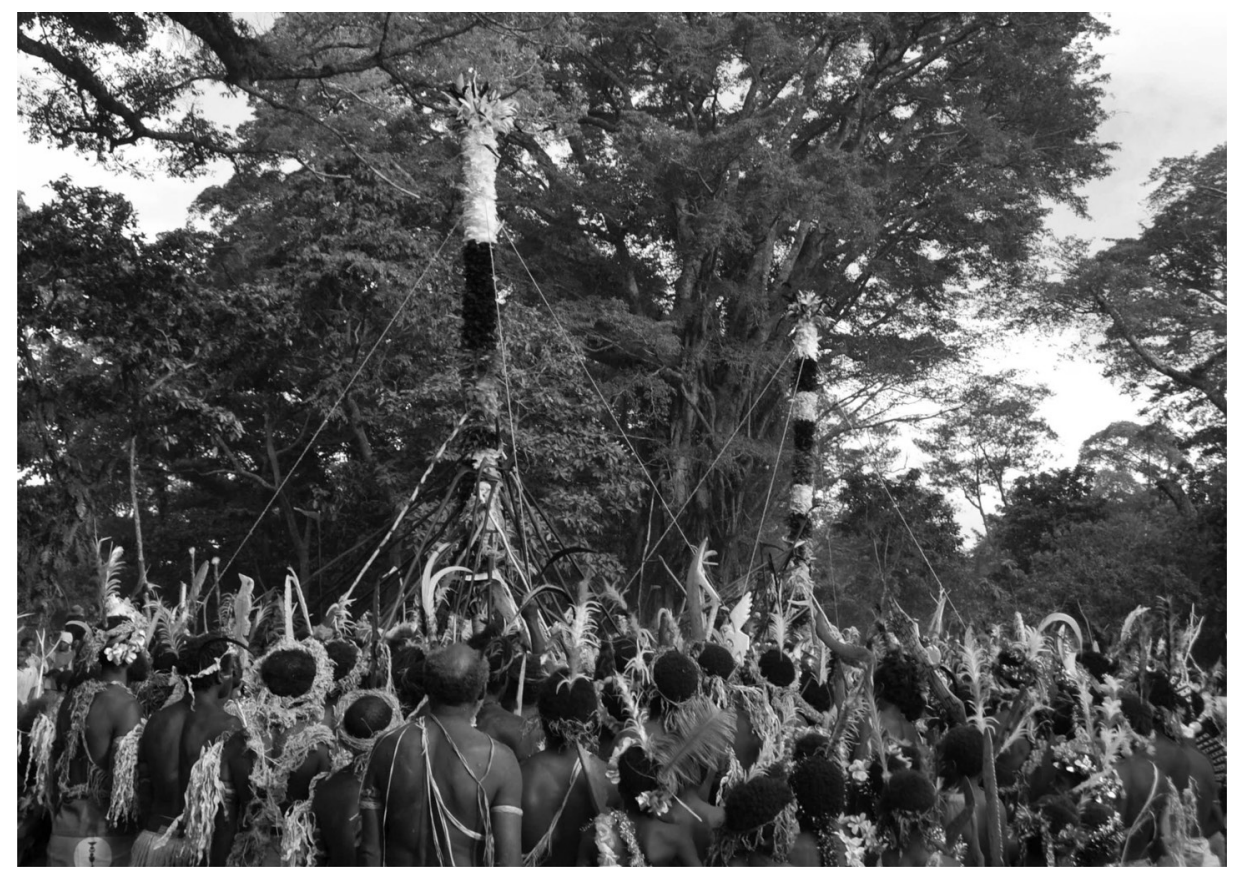

FIGURE 2 Iermenu and his followers carrying a kwerrya pole for a nakwiairi ceremony in Mwaterkerek, Tanna, September 20Io. (C) Philippe Métois; reproduced with permission. 
of allegiance is given by men of several nemwipwi belonging to the same mythical and territorial unit called a neteta or canoe and linked together through the nakwiari network. Tanna has over a hundred neteta (sometimes imperfectly translated as "tribes") and each one can include several ieni neteta dignitaries (also spelled ieni entete). These "masters" or "spokesmen" of the "canoe" (Guiart I956, 88) are guarantors of peace and war within the neteta, a mythological territory deeply rooted in a living "terroir" where ancestors were part of the social and natural landscape.

Dignitaries or notables who could claim the titles of iermenu or ieni neteta in precolonial times were certainly well positioned to gain the prestige of a "big man" figure (nakur asori or nema asori). However, it may have been possible to acquire that status without any titles, through an ability to influence group decisions using personal knowledge (Lindstrom I98I). Conversely, to be renowned as a big man offers the possibility, through genealogical manipulations, of gaining a title: "Many local big men become ierumanu or ieni entete after they are first big men" (Lindstrom I98I, 69). During colonial rule, acquiring big man status was an advantage for being appointed a Christian chief by the missions or an assessor by district agents. But along with such developments, in the wake of the rise of the prophetic John Frum movement, different new syncretistic dignitary statuses appeared: "prophet," "spokesman," "captain," "police," or “army” (Tabani 2008).

With the country's approaching independence, the politicization of kastom became particularly virulent. Local movements and groups upgraded into political parties (John Frum, Kapiel, Fokona) that more or less accepted the principle of universal suffrage and whose main ideological rhetoric was to oppose kastom to politik. Assessors' positions or Christian chiefs' appointments started to become a burden for many big men or titleholders who could be accused of standing as "giaman [false] jifs" because of their colonial affiliation. On Tanna, the general political antagonisms and tensions between nationalist followers and traditionalist forces gradually increased until the secession attempt organized in 1980 by traditionalist groups opposed to an independence governed by nationalist Christian groups. The fear of seeing these struggles develop into an open civil war brought the traditional war leaders back to the forefront. Peaceful times, which are more propitious to the exercise of the iermenu's responsibilities in ceremonial exchanges, came to a temporary end. The "spokesmen of the canoe" dignitaries were better armed to face the new contentious challenge created by accession to independence. As we see in the next sec- 
tion, on Tanna the bureaucratization of chiefs through repeated attempts at codifying kastom favored the rise and prestige of the ieni neteta, who traditionally hold the role of talking chiefs in the context of a sovereign state in need of local mediators to establish its new legitimacy.

\section{Bureaucratization of Chiefs and Codification of KASTOM IN TANnA}

After World War II, “native courts," first appointed by the condominium in I9I2, started to lose their efficiency in maintaining law and order. Since the I940s, colonial district agents assisted by their indigenous district assessors had to face the John Frum rebellion. While encouraging a generalized return to kastom and traditional forms of authority, this movement brought to an end the unchallenged hegemony of Christian chiefs and put a stop to the blind repression by church and colonial authorities of pagan traditions and John Frum beliefs. Condominium authorities encouraged, in the I950s, the establishment of indigenous "local councils," with official authority in most civil matters. However, until independence, the French and British never succeeded in empowering these councils, since nobody could agree on the designation of indigenous representatives: "The lack of any clearly defined system of chieftainship on the principal island of Tanna was the major obstacle to the rapid establishment of the chiefly Electoral College [body of electors for the Representative Assembly]" (Woodward 2014, 52).

In I968, Iolu Abil a young educated Tannese, who later would become president of the Republic of Vanuatu, tried to launch a project to set up a local consultative council in order to federate the island's population. Abil gave his proposed council the name "Iani Niko" (in Lenakel language: Spokesman of the Canoe). Its purpose was to act as a supra-local island forum, enabling a collectively instituted indigenous opinion to be given on any political or economic developments. This consultative council could also have provided a future democratic foundation on which to base political emancipation from the colonial system. But what could have become a positive contribution to the modern political history of the Tannese led to the opposite. Although claiming that the Iani Niko council was a "customary parliament," Abil rapidly generated a great deal of hostility toward his project among traditionalist dignitaries. The whole operation was considered by its opponents as a way to politicize Tannese kastom for nationalist claims and search for personal power: "The Iani Niko [coun- 
cil] became a crucible in which all [the former colonial] political and religious divisions were renewed" (Bonnemaison I987, 442).

The Iani Niko council also became a subject of division between British and French authorities. The first supported the unifying intentions of its project, while the second stressed its divisive aspects. As a result, the Iani Niko council received no official recognition. A new attempt on behalf of this council to be acknowledged as a legal institution was launched a couple of years later. After it had changed its name to Nikoletan ("The Land Canoe") in I973, a new demand to be allowed to play the role of a representative political structure was rejected for the same reasons as before. The British district agent in Tanna heavily criticized his French colleague, accusing him of "discouraging any local political initiative and supporting different movements which have a strong tendency to be influenced by colonialist and reactionary forces"; in his answer, the French district agent emphasized that he refused to grant any power to a minority group formed by a young anglophone Christian elite and clearly calling for the country's urgent independence (Bonnemaison I987, 443).

The lack of a supra-local structure among the Tannese for discussing the future of their island and sovereign country led both francophonetraditionalist and anglophone-nationalist groups toward escalating tensions. This situation ended with the failure of the francophone groups and parties, both locally and nationally, to win the 1979 elections for the Constituent Assembly. In June I980, one month before the proclamation of the independence of Vanuatu, they tried to launch a rebellion against the nationalists but definitively lost the battle when their leader Alexis Yolou was killed. Finally, the new government of Vanuatu, formed by Anglophones (mostly clergymen of the Presbyterian Church) and the National Council of Chiefs (the Malvatumauri) rapidly granted official legitimacy to the Nikoletan (figure 3 ).

In I983, the Malvatumauri published its first "traditional cultural policy" draft or kastom polisi (Lindstrom and White I994). Its main purposes were to protect existing kastom in rural places and to promote a national synthesis of local, codified traditions. However, as mentioned earlier, this text provides no harmonization of chiefly status due to an obvious incapacity to define or codify kastom at a national level. Amid the different topics addressed by the Malvatumauri's policy, article 20 (devoted to the "chiefs' organization in Vanuatu") is obviously the most minimalist: "Sec. I: Plans for the work of chiefs in Vanuatu must continue and develop further in the future. Sec.2: There must be a National Council of Chiefs in 
Vanuatu and island councils of chiefs, and area councils of chiefs, and village councils of chiefs in order to promote custom chiefs in the Republic of Vanuatu" (quoted in Lindstrom and White I994, 242). Article 29, section I of the Constitution of the Republic of Vanuatu only adds more imprecision about chiefly representatives: "The National Council of Chiefs shall be composed of custom chiefs elected by their peers sitting in District Councils of Chiefs" (Government of the Republic of Vanuatu I980).

Thus, the business of codifying kastom was delegated to the island or district council level. In Tanna, the Nikoletan council swiftly began the task with considerable enthusiasm. Some of its members formed a committee to work on a "Tanna island kastom" project. A forty-five-page booklet written in Bislama was typed and, in I985, officially declared by this neocustomary body to be "the true kastom law of Tanna" (D’Arcy I994, 6). This document is remarkable in many of its contradictory aspects, but its main interest lies in how it tries to codify selected, nondiversified elements of local customs by focusing obsessively on the power of chiefs. According to its subtitle, "true kastom" on the island is the "Law of Tanna Chiefs."

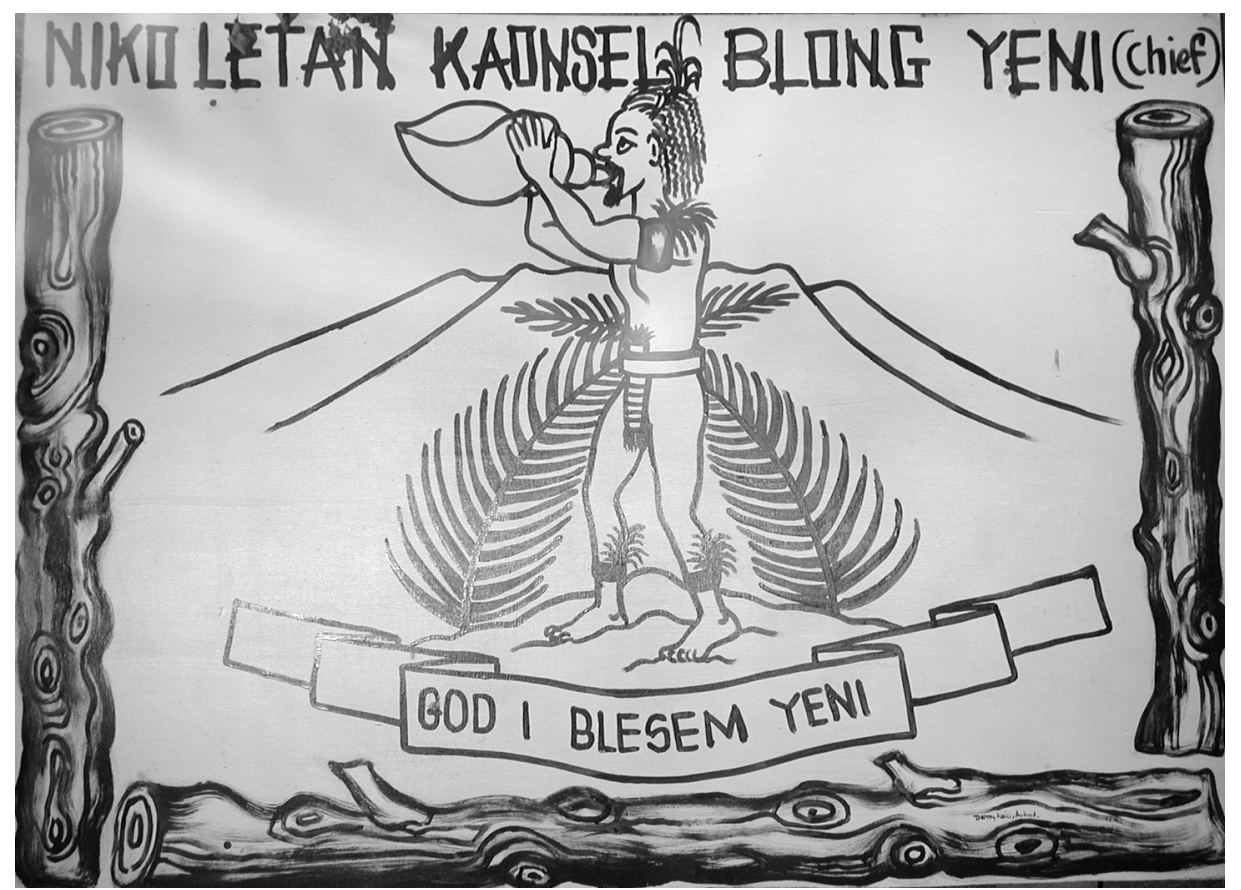

FIgURE 3 Logo and motto of the Nikoletan council of iani, July 20 I I. (C) Marc Tabani. 


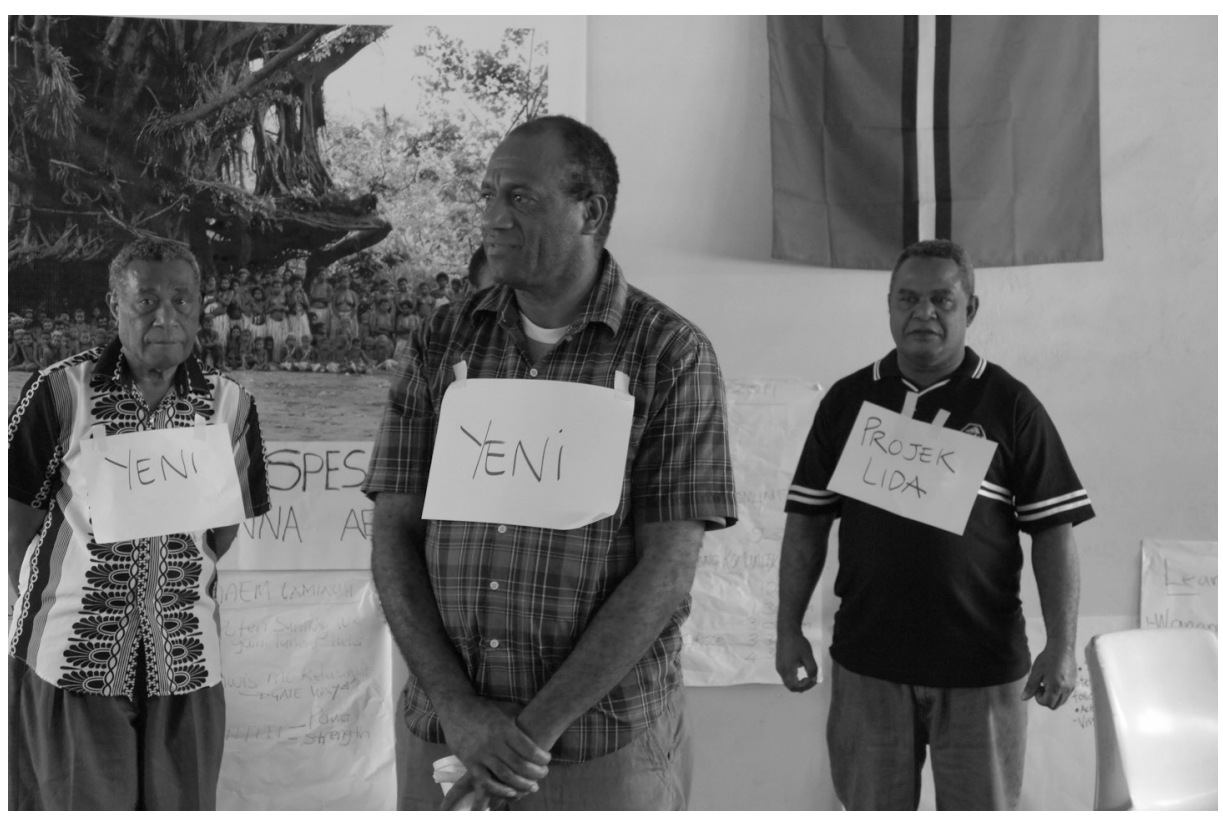

Figure 4 Yeni (or iani) present their duties as chiefs at a workshop on kastom governance in Lenakel, Tanna, July 20I I. (C) Marc Tabani.

Those on the committee for this project, like all other members of the Nikoletan, were supposed to have acquired or be able to lay claim to a iani niko title. Therefore, it is not surprising that, in their standardization of chiefly figures, they proclaimed themselves to be those most eligible to be in charge of kastom governance matters. In fact, two types of chiefs were put forward: “Art.2 Law concerning Chiefs of Tanna: In the beginning, iani and iaramara both came out of the stone. Iani is the chief of everything, in the name of iaramara" (D’Arcy I994, I I).

As iani are responsible for everyone who belongs to the kastom of Tanna and are the sole dignitaries authorized to give orders, their "voice is holy and must be respected and honored" (D’Arcy I994, I I). But otherwise, iaramara are mostly mentioned for their special duties and responsibilities regarding the ritual organization of the nikouiar ceremony. The main chiefly role is definitively occupied by the iani titleholders. To secure their position, they themselves decided that

custom law was reintroduced to forbid men from talking in the meetings. The right to talk in meetings belongs to the chiefs. Other people who are forbidden to talk in meetings are: manamana (supporters of the chiefs), all iaramara (high 
chiefs), and all tupunis (special people who work with stones [agrarian magicians], etc), none of these people have the right to talk in the meeting where chiefs only have the right to talk. (D’Arcy I994, I 2)

A marked intention of the writers of this code is to impose a strong hierarchy, with iani and iaramara at the top of the ladder, followed by other dignitaries who must show allegiance to the former and then by subaltern categories of commoners. The status of iaramara is seen as symbolizing the powers of kastom, but the iani represent the strong arm of its law. This three-stage rocket of neo-customary authority would henceforth be recurrent in much bureaucratic standardization or homogenization of chiefs and kastom on Tanna, adding sometimes to the "chief" status such curious titles as "paramount," "king," or "big king” (figures 5 and 6). Moreover, since the chiefs' power over kastom had been written down, no further contestation over the interpretation of this text would be allowed. The Tannese have several languages, but the history of the island "from time before until today was that we the people of Tanna have ONE KASTOM LAW" (D’Arcy I994, 5).

The "Niko Letan Kanstituson" of 2006 is an essential addition to the I985 "Tanna Kastom Law." Both kastom codices are quite different in their overall purpose and the second, written twenty-one years after the first, arose in a different political context. But once more, a privileged position is given to the $i a n i$. This constitution represents complete coronation for them: "God bless the yeni" (article 6). It proclaims that yeni are the highest kastom rulers: "The yeni is the paramount chief chosen by a tribe according to his chiefly blood line" (article 20). Each tribe must have a yeni, and his authority is guaranteed lifelong (articles 2I, 22). The president or head of the Nikoletan council, "after having been chosen by the means of kastom, culture and traditional beliefs, becomes the Paramount Chief of the island" (article 25). Maintaining the hegemony of yeni chiefs also supposes getting rid of all confusion about the alleged customary origin of their privileges, in order to neutralize possible attempts to usurp their power. Several articles are devoted to this work of clarification:

Criteria to be a yeni. Art.26 The yeni has always been, he was there before anyone. Art.27. The yeni is appointed in accordance with his bloodline. Art.28 Yeni is a special kastom name for a tribe. Art.29 The yeni is not: a tupunis; a yeramara; the political commissar of a political party; an elected councilor of a local authority (Provincial Gvt, Municipal, etc.); a Parlement Member; a Pastor, a Father except if they follow the line of the yeni. (Niko Letan 2006) 


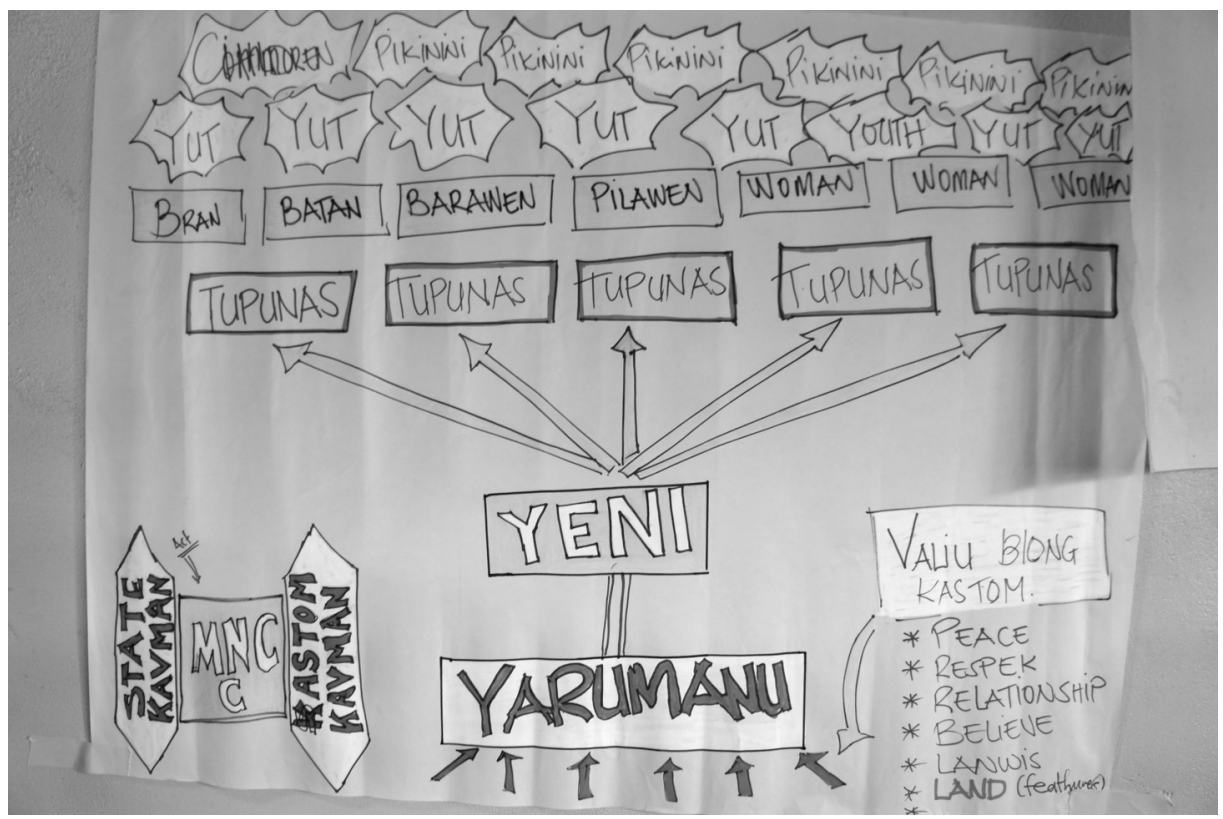

FIgURE 5 Diagram of a standardized vision of the structure of authority in Tanna, at a workshop on kastom governance in Lenakel, Tanna, July 20 I I. (C) Marc Tabani.

The only other codification work in the constitution is devoted to the way yeni representatives are designated at different tribal-area levels and how they are encompassed at the island level. Otherwise, this Nikoletan constitution is resolutely modernist and bureaucratic. It takes a very juridical turn, referring to "supreme law" and "supreme bodies" and claiming a copyright on anything that has a "kastom symbolic meaning." Several chapters are devoted to procedural rules, executive organization, and secretary or treasurer appointments. Special emphasis is laid on the different levels (state, island, area) of sovereignty. This latter aspect was stressed by the chairman of the Malvatumauri National Council of Chiefs, Chief Paul Tahi, when he came to Port Vila to launch the first constitution of the Nikoletan Council of Chiefs on Tanna in May 2006:

In his official address in front of more than 3,000 men, women and children who witnessed the ceremony, Chief Tahi said . . . the Malvatumauri National Council of Chiefs recognizes the Nikoletan Constitution and the Malvatumauri will make sure that the Government recognize the constitution promoted by the custom chiefs of Tanna . . . the "bubu loa" [ancestral law] of Tanna.... 
Chiefly Structure on Tanna

(According to senior Tannese source)

laramara

(Paramount Chief/Big King)

I

Iani

(King of the tribes, Chief's spokesman)

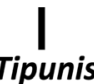

(Hold stones in charge of weather)

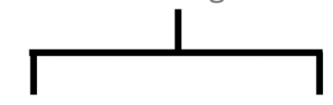

Numaninatik Manamana

(Group of People) (Group of People)

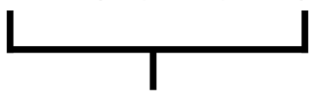

Nias (Family Groups)

Figure 6 Standardized diagram of "chiefly structure on Tanna." (C) Nixon, Leisande, and Raewyn 20I2, I2; reproduced with permission.

He called on the people of Tanna to treat at all times the Nikoletan Constitution as the rightful custom laws that govern the twelve nakamal of Tanna and also remember that Vanuatu's Constitution is the "mama loa" [Mama Law]. (Vanuatu Daily Post, I6 May 2006)

\section{Tannese Kastom and the “Twelve Nakamal” Organization}

This emphasis on the institutional legitimation of the Nikoletan by the Malvatumauri, almost three decades after the consecutive creation of these two councils of chiefs, may appear surprising. The attempt to depoliticize chiefs-making them dependent on state power according to the government's will to consider that kastom should transcend the infra-national divisions inherited from colonization-seemed to have been long over. Despite the claimed anteriority of ancestral law (bubu loa) over the Constitution (mama loa) of the Republic of Vanuatu, the latter stipulates that it is up to the state to validate local variations of kastom and not the oppo- 
site. Less familiar to a reader of the Vanuatu Daily Post not from Tanna is the reminder of state sovereignty and the prominence of the Nikoletan over the Twelve Nakamal (TN). On Tanna, there are hundreds of nakamal (imwarem in Kwamara language, iimwaiimw in Lenakel language), places set aside for kava ceremonies and the organization of traditional dances. The twelve concerned here refer to those supposed to be entitled to host the great nakwiari ceremony-a selection that is not traditionally unanimously approved. But in more concrete terms, the expression refers to an organization of the same name, which also possesses a constitution, dating from the 27 June 2006 and signed by the twelve "chiefs" (iani) of these nakamal.

Behind the matter of this "TN" organization, we find vague opportunistic desires to exploit Tanna's kastom for political purposes internal to the island, coupled with political and commercial aims inspired by external national and international covetousness. It began with the collusion of interests of a New Caledonian photographer and French diplomatic networks. The former, it seems, wanted to make it easier for himself to attend a nakwiari ceremony, which is organized according to a complex calendar, sometimes every year and sometimes with a break of several years. He hoped to curry favor with President Jacques Chirac by approaching the francophile tribes most able to give the president, for the inauguration of his Quai Branly Museum, the "ambassador objects" worthy of being part of the "dialogue of cultures" vaunted by this establishment. The French Embassy in Port Vila and the High Commission of New Caledonia were contacted. Old local mythologies about the French ship Kersaint coming in I9I 2 to "save the custom of Tanna" from the Presbyterian missionaries were recalled. "This story (of the Kersaint) has remained in the collective memory of the inhabitants of Tanna, who since then have felt they owe a debt to France," explained Pierre Mayaudon, the French ambassador to Vanuatu (Agence France-Presse, 3 June 2006).

So, in thanks, a chief from the east of the island was willing to give a kwerrya to France. This feathered ritual pole about three meters high, made of an armature of coconut palm ribs, covered in multicolored chicken feathers and topped with sparrow hawk (kwerrya) feathers, is considered to be the symbol of the nakwiari masters (iermenu) (see figure 2). On the Tannese side, the kwerrya affair would soon snowball. Under the management of several directors of government services in the capital and leaders of pro-French political parties (National Community Association, Green Party), a number of local dignitaries were approached. The choice fell on 
Chief Yaukalepwi (also sometimes spelled Iaukalpi), one of the two iani of Yanamwakel in the White Sands region, in the east of the island. Both dignitaries are traditionally the guardians of two long stones whose shape was similar to that of Polynesian adzes: “The largest stone, the 'elder' one, was called Numrukwen, the other Koyometa. . . . The island's existence still seems quite generally to be considered partly determined by the preservation of these stones whose loss would represent a kind of national catastrophe" (Guiart I956, 66). These mythological stones go back to the dualistic system that structured social and spatial organization and was destroyed in the nineteenth century at the end of the wars between moieties affiliated under these names. However, the Yanamwakel nakamal has not been considered suitable for the organization of a nakwiari for decades. But beyond the noncustomary dance place that was used for the August 2005 ceremony, it was the legitimacy of this entire nakwiari that was challenged by many of the island's customary dignitaries. This great ceremony of peace would throw Tanna into discord. Two kwerrya were specially prepared there as gifts to foreign countries: one for France and a second one for China (the latter was in the end never exported, as it was blocked in the island by Tannese opponents).

This gesture acquired its full significance as the whole undertaking became more and more excessive: a French Navy ship, the Jacques Cartier, was given the mission of fetching the kwerrya from the village of Yanamwakel at the beginning of November 2005. On this occasion, officers and sailors disembarked to take part in a second gifting ceremony that bore little resemblance to custom. A camera crew came specially from France to make a film about the event as well as to publish a book about it (Ghezelbash 2006; Darmayan and Ghezelbash 2006). Finally, in June 2006, Chief Yaukalepwi himself was invited to the inauguration of the Quai Branly Museum in order to present, in person and wearing traditional dress, the feathered pole he had entrusted to the museum, to Jacques Chirac, and to then United Nations Secretary-General Kofi Annan (figure 7). On his return, he spread rumors in the bush about the independence for Tanna he claimed to have negotiated with these two personalities, thanks to his gift. This theme, common in Tanna, of a recolonization of the island by France and its incorporation into New Caledonia, met with even more approval than usual among the large local francophone population.

The whole business surrounding the "Tanna feather" put the governing authorities in a very awkward position. They gave the Nikoletan the task of sorting out this affair. The situation seemed to resemble that occasioned 


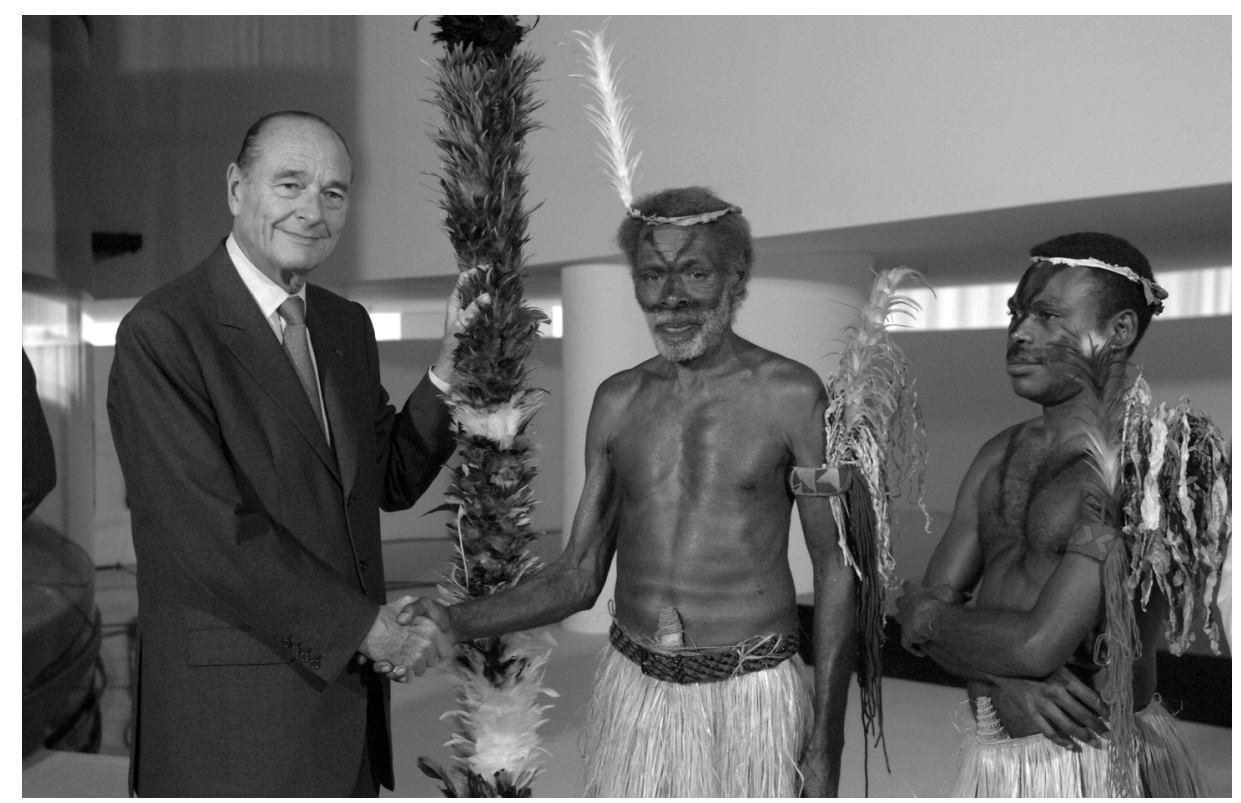

FIGURE 7 Chief Yaukalepwi and his nephew Jerry Napat giving a kwerrya to French President Jacques Chirac at the Musée du Quai Branly, Paris, 20 June 2006. () Gamma-Rapho; reproduced with permission.

two years earlier, when a deputy from the Vanuatu Green Party, Moana Carcasses, went to Tahiti to take advantage of President Chirac's visit there in order to present Chirac with honorary customary Vanuatu titles, including that of "tapunga" of Tanna. On this occasion, the Nikoletan expressed itself in extremely crude terms by declaring to the press that the name "tapunga was not a prostitute!":

The Island Council of Tanna Chiefs, Nikoletan, has voiced its concern over the bestowal of the traditional name "tapunga" to the French President Jacques Chirac, by a group of local politicians. In a letter of concern written to the Ministry of Internal Affairs, the chairman of the Niko Le Ten Council of Chiefs, Chief Pita Nimaulul, brought to the minister's attention that no approval had been given by his chiefs for the use of the name. ... "This matter has not been approved and in relation to our custom and its function, such a party and its MPs, which have abused the custom, should be punished according to our custom laws," emphasized Chief Nimaulul. He stated that according to custom, "tapunga" is not a name given to any ordinary person, but specially for the purpose of rebuilding the relationship between iani and iaramara, whenever one has done something wrong to the other. (Port Vila Presse, 23 Sept 2003) ${ }^{5}$ 
But this time it emerged that the gift of the kwerrya to France appeared to be the tip of the iceberg and was actually part of a much broader and more premeditated program. Rather than run the risk of being attacked by the Nikoletan, it was thought better to challenge its legitimacy and to attempt to replace it with a new customary council, seen as more respectful of traditional rules. With the help of a Tannese jurist, a loose conglomeration of protagonists in Port Vila published a "Constitution of the Twelve Nakamal of Tanna Island." By mobilizing local networks on the island, they gained the support of the "chiefs" of these twelve dance places for this constitution, which they personally signed on 27 January 2006. This was the beginning of a trial of strength with the Nikoletan, which managed to produce its own new constitution several months later, in May 2006. During the interval, the Nikoletan's strategy for opposing the TN was based on challenging Chief Yaukalepwi's customary right to give a kwerrya to France and, more especially, on questioning the very existence of his "chiefly" status. In the days following the presentation of the feather to the Quai Branly Museum, Moses Nasu Kasaually, from the same village as Yaukalepwi, expressed himself in the Vanuatu press concerning the kwerrya, stating that it was the equivalent of his iermenu crown and that, under the guise of a gift, it was in fact a question of exporting, misusing, and misappropriating a sacred object.

Vanuatu's gift of a kwerrya feather to French President Jacques Chirac has been questioned by a Tanna man, who claims to be the rightful owner of the feather, Vanuatu Daily Post reports. Moses Nasu Kasaually from Yanamwakel village told the newspaper that he was not consulted by chief Iaukalpi, who made the presentation to President Chirac in Paris last month. $\mathrm{Mr}$ Kasaually described the presentation of the gift as the selling of his birthright to France. He said chief Iaukalpi did not have the customary right to take the gift to France. Mr Kasaually said the kwerrya feather was his crown and chief Iaukalpi has now decided to sell it off cheaply to France. (Pacnews, I 8 July 2006)

I was able to talk with Kasaually, and during our conversations, he stressed the fact that Yaukalepwi was an adopted child and, in his view, had illegitimately received a name that enabled him to acquire the iani niko title. Some of the francophone groups of Tanna joined this dispute, insofar as the Yaukalepwi group was originally associated with the Presbyterian mission and that they saw in the latter's approach a strategy for regaining their historic relationship with France, for whom they had 
"given their blood." At Kasaually's request, this mobilization led to the holding of a customary meeting in late October 2006, attended by all the chiefs from the east of the island. In front of all the Tannese protagonists in this affair and several hundred witnesses, Kasaually decided to strip Yaukalepwi of his iani niko title. This measure-previously unheard of in customary terms, if we are to believe the participants-opened up the way for institutional proceedings conducted by the Nikoletan, which up until then had paradoxically kept out of this strictly customary procedure. At a meeting of the Nikoletan, an official letter of protest, dated I November 2006, was addressed in anglicized Bislama to the French Ambassador in Port Vila. Below are the main extracts as they appeared in the letter:

Re: Kweria (Crown) of Tannese King that was taken to new Museum in France.

Niko Letan Council of Chiefs, the last and highest traditional decision making body on Tanna wishes to express its disappointment over the way the Kweria Crown was taken to France without proper consultation with Niko Letan Council of Chiefs.

Kweria is a Tannese (people of Tanna) highest Chiefly identity. That should not ever, ever be given away to anyone or other country without consulting those responsible for custom and tradition of the people of Tanna. Giving away Kweria Crown to foreign person or foreign country is like selling your birthright as far as Tannese culture is concerned.

Kweria to France has caused divisions among the chiefs of Tanna and their various tribes. ... Niko Letan suggested that, Yaukalepwi and French Ambassador arrange a peace ceremony and apologies to Niko Letan Council of Chiefs and to the people of Tanna for such action. After the peace ceremony, Niko Letan will then decide if the Kweria be returned to Tanna or can be kept in France with certain conditions apply.

Niko Letan Council of Chiefs on behalf of Tannese communities requested Mr. Marc Tabani who is a French researcher to convey our dissatisfaction both to the France Ambassador to Vanuatu and to the French Government for such an irresponsible behavior. In the meantime, Niko Letan Councils of Chiefs will investigate Chief Yaukalepwi's real intention behind sending Kweria to France.

I myself handed this letter to the French Ambassador, but it remained unanswered. No ceremony of apology was organized and the kwerrya on the banks of the Seine has to date not been returned. Similarly, the destitution of Yaukalepwi seems to have had no effect, insofar as the latter's local and national support has remained strong. The existence of the TN is still a reality, even if it has become more discreet. 


\section{A New Constitution to Make Tannese Chiefs Great Again}

The TNs' constitution takes the form of a thirteen-page document with fifty-two articles, signed by the chiefs representing these dominant nakamal and a few witnesses, including the Tannese jurist behind the writing of it and an administrative representative of the district. ${ }^{6}$ Beneath its cursory and sketchy aspects, the content of this text does indeed represent a founding charter for a total reestablishment of customary powers: "Constitution' in the present law means the Supreme Customary Law of Tanna" (article 49). Its objective is seditious, similar to a customary coup d'état founding an island sovereignty: "It is custom which becomes law on the island of Tanna" (article 52). Using the Constitution of Vanuatu's acknowledgment of custom as a law and in accordance with the first Nikoletan Constitution (I98I) describing the customary law of Tanna, the TN declared themselves, due to their anteriority, the "supreme body of the custom of Tanna and the Nikoletan Council of Chiefs is one of its branches or children. The TN has full power to control anything belonging to the Tannese custom" (article 2 b). Under certain conditions, some powers can be delegated to the Nikoletan (article I 5 a), but it is placed in a position of total subordination: "The TN has the permanent power to revise and amend the Nikoletan Constitution" (article I $_{5}$ b), to "appoint its executive members . . . to suspend or dismiss them" (article I 2e). To this principle of "supremacy" is added that of "independence" (article 2d). Even certain safeguards may appear suspect: the TN "wishes to work with the Vanuatu government, the provincial government and with all government bodies or NGOs or any other body in order to promote custom" (article I2) and "agrees to work with the police or with any other government body to maintain peace and order in society" (article 36).

Curiously, the details of custom are never described in this constitution, but it is to be applied fully. It can also be noted that there is very little stress on the dominant role of the iani and the grounds for their domination. The essence of custom, like that of chiefs, henceforth goes without saying. The stated objective is explicitly to hierarchize the iani themselves: those of the TN are the supreme chiefs who represent the "twelve tribes of Tanna" (article 7c); "all the other chiefs are inferior to them" (article 9). These supreme chiefs have the prerogative of nominating all the other dignitaries (article 20). They have the exclusive right to appoint the nonhereditary chiefs (article 44). These laws aim at establishing a custom- 
ary dictatorship of the TN chiefs over those of the "little nakamal" that are their "kitchens" (article 20). These minor chiefs are divided into five hierarchized categories in which the iaramanang surprisingly occupy an intermediate position, behind the "tupunis" (agrarian magicians) and the "police" (article 20). The TNs' absolutist power is exercised over everything concerning the use of land (identification of customary owners, disputes over land ownership, signing of leases), development projects, and economic investments (articles 28, 34, 39, 40). An essential point of this despotic power or its delegation is the control claimed by the TN chiefs over titles and names, over "chiefly titles" (article 28), and "in the origins of every man Tanna" (article 29): "in the future, the TN will keep a file on each chief of Tanna whether on Tanna or in Port Vila" (article 29c). This Orwellian vision of chiefs' power, as envisaged by the TN, takes on almost totalitarian tones in an exclusive power of nomination, that is to say of a totally oligarchic attribution of chiefly titles, so as to reduce to nothing all customary claims contrary to the interests of this organization:

Art. 46. Customary name

(a) Without the written permission of the Twelve Nakamal or their representative, no chief can give a customary name to an individual or institution.

(b) All names already attributed are removed and only returned following the procedure mentioned above.

(c) All customary names belong to the Twelve Nakamal.

Despite the absolute power the "supreme chiefs" of the TN attempted to assume with their constitution, in reality, it gave them little more authority than that given by the Nikoletan to its own representatives. In fact, the philosophy behind each of these constitutions is very similar, since in both cases it is a matter of prohibiting any other kind of leader from becoming a kastom if in place of the iani (whatever the legality of the organization to which they belong). However, the TNs' constitution is innovative on one key point. It proclaims the authority of the twelve chiefs over any form of land use on Tanna for economic purposes, whether traditional or modern, and seeks to legitimate and validate their claim to an exclusive copyright on the customary names and titles of all Tannese men. These "supreme chiefs" thus defined hitherto unheard-of possibilities for controlling land ownership, making it easier for land to be seized. In comparison, the Nikoletan keeps to the general principles defined by the Constitution of Vanuatu concerning "customary owners," who according to a very 
vague expression are "citizens of indigenous origin." But the Nikoletan has never departed from the Tannese customary rule that no "chief" can claim possession of land. Chiefs of this island exercise power over men, but never over land; as the expression goes on Tanna, "Jif hemi jif blong man, hemi no jif blong kraon."

At independence, the question of returning land to "customary owners" was discussed on Tanna, in a purely formal fashion, as actual alienation of land-that is, its exploitation or use for commercial productive purposes or for infrastructure needs-was very rare there. Even today, compared to the serious problems of land seizure experienced by the country's other large islands, on Tanna there have been only a minimal number of long leases, which for the most part concern sites for collective or administrative structures, churches, and, in the private sector, tourist facilities. The bad reputation sometimes given to the people of Tanna continues to discourage foreign investors' attempts to alienate their land. Thus, over the past twenty years, the growing covetousness for land on Tanna has stirred up conflicts within the community. Whether these disputes are between groups, organizations, or individuals claiming to represent them, the points on which disagreements are focused remain in most cases related to situations and rules predating those introduced by colonization. Former customary practices continue to be used for settling land problems on Tanna, even when the present-day stakes involved in these conflicts concern financial issues regarding land that nowadays has a market value. The aim henceforth is to adapt these rules to contemporary economic needs. Chiefs should now be able to become guarantors of the land tenure or economic transactions decided on Tanna, even if this involves a strengthening of their personal power, unconnected with the will of the people and customary rules.

Encouraged by international agencies, the government has given priority to their determination to harmonize or even standardize land tenure rules on a national scale. Locally, initiatives encouraging the implementation of this are mostly the work of the new generations of educated Islanders with positions of responsibility in the public or private sector and access to numerous political and media relays in Vanuatu as well as abroad. As the latter generally possess no deep knowledge of kastom, the simplest means of acting locally is to exert influence on chiefs who, ideally, would exercise effective power and, above all, could carry weight in economic projects. However sincere the intentions of educated advisors may be, their conception of the exploitation of land and more generally their 
economic models tend to move irremediably away from the utopian vision of development in the service of Melanesian custom and values believed in by earlier generations at the time of independence. In using kastom for non-customary purposes, they would seem at times to have marked a turning point in comparison with their elders. The power that custom was able to demonstrate in the past in order to prevent foreigners from interfering in the internal affairs of Tannese society seems to have reached its limits.

\section{Conclusion: The Future of Chiefs}

In Tonga, where physical stature was associated with a high social status, the identification of chiefs may have been easier for the inexperienced outside observer. As an informant pointed out in reply to an early ethnographer's question: “Can't you see he is a chief? See how big he is" (Gifford I929, I 24). In Vanuatu, this identification remains extremely complex, even for the country's leaders who know its cultures. According to government minister Ralph Regenvanu, despite the institutional role given to "state chiefs" and the marks of respect generally spontaneously accorded to any individual assimilated to a "chief," legislating on the position of chiefs and their legal power is still a problem:

So, we're stuck in a dead end-we can keep giving power to chiefs in laws, and yet have a position in which the laws are ineffectual because you don't know who the chiefs are and anyone can step up, and then they're contested. To move forward on the issues of chiefs being involved in governance we're going to need to solve that problem. (Geismar and Regenvanu 20I I, 42)

Regenvanu sees the solution to this issue in the modernization of a bureaucratic system for recording chiefs, which would seem not to have worked previously because most chiefs are against it. It must be admitted that a consensual, democratic system for designating chiefs seems a long way from kastom:

The chief is nominated. The people who have to sign are the leader of the churches, the leader of the women, the leader of the youth, the leader of each clan, and then chiefs of neighbouring villages. If they all sign: this is the chief. (Geismar and Regenvanu 20I I, 43)

An extraordinary paradox emerges here. What will become of the role and rule of customary chiefs, who would no longer be chiefs by virtue of 
the custom they are supposed to represent? The problem therefore stems more from the question of kastom than from the historical status of chiefs. The Ni-Vanuatu often repeat as a leitmotiv that many new social problems affecting rural communities are due to an erosion of custom, which finds expression in a loss of respect for chiefs and ignorance of the powers handed down to them by their ancestors. The weakening of kastom is systematically attributed to foreign cultural influences and the totalizing economic ascendancy of money. The rampart of kastom proposed to counteract the generalized disruption of values would seem to have been submerged. But this kastom applied as a cultural corrective for the $\mathrm{Ni}$-Vanuatu, in the form of an argument aimed at distinguishing it from the culture of Europeans and more generally of all foreigners, is today also threatened by nontraditional and non-Melanesian ways of treating custom. This is particularly the case for everything linked to the question of chiefs and the "customary" nature of their power. For what would become of their power outside custom?

Opinions are divided. For Regenvanu, the solution necessarily involves an institutional modernization of custom. He supports the paradoxical approach followed by the National Council of Chiefs of removing power from chiefs: "power has been given to the councils of chiefs, not [to] the chiefs" (Geismar and Regenvanu 20II, 43). Power would be held by the twelve island councils (plus the two urban councils of Port Vila and Luganville), whose only customary element would then be their name. For current Prime Minister Charlot Salwai, quite the reverse: the problem lies in the fact that chiefs have moved away from custom. On the occasion of the National Day of Chiefs, he declared in front of the Malvatumauri chiefs that "our challenge today is to maintain the status and authority of the chiefs around Vanuatu at the time now that external culture is increasing in our society. ... While we can regulate the functions and pass laws to recognize the chiefs and their roles, we must at the same time be careful not to lose the fundamental custom duties and values connected with a chief to exercise his role and authority in customary responsibilities" (Vanuatu Daily Post, Io March 2016).

However, the supporters of both positions agree on the same conclusion: custom grows weaker when the number of individuals claiming to be chiefs through custom is far too large. As Prime Minister Salwai stated, "Today, there are too many men claiming chiefly titles and I believe that the full process of custom practices in our respective islands must be fully applied so as to determine a right chief in line with the customary belief 
that we in the Malvatumauri are aware of these challenges" (Vanuatu Daily Post, Io March 2016). Rectifying the situation of chiefs in order to restore full value to custom is like sweeping the Augean stables. Nothing seems to have fundamentally changed since the institutionalization of state $j i f s$ in the I970s and the permanent temptation to create an administrative hierarchy of them. Even the development agencies are not insensitive to this enduring problem and to the issues it raises in terms of stability, social control and obstacles to "development." For instance, in the 2000 , Vanuatu received A $\$ 2.5$ million from AusAID for a vast study on customary governance (Vanuatu Kastom Governance Partnership) intended to modernize the way it functioned. Its experts had no hesitation in interfering in the defining sanctuary of kastom and thus in meddling with a cultural heritage. In AusAID's view of the world, the populations of Vanuatu should rely exclusively on those "good" customary values that make it possible to realize that the natural and cultural heritages of Pacific Islands possess real resources and that an enlightened custom would not hinder the use of them.

The great relevance of the chiefs to development in Vanuatu means that it is necessary for AusAID to engage with them as development partners.... Through the Partnership, AusAID is potentially supporting one particular view of kastom. The involvement of foreigners in anything to do with kastom is highly sensitive, and both ACPACs [Australian Centre for Peace and Conflict Studies] and AusAID have had to be conscious of the perception that they are interfering in indigenous matters. The socially conservative nature of many (but not all) chiefs and the patriarchal nature of the chiefly system favored by Malvatumauri means that AusAID and Malvatumauri hold different values on certain issues, such as gender equality. (AusAID 20I2, 24)

According to these experts, "the concept of 'kastom' is a relatively recent social construct associated with the independence movement" (AusAID 2OI 2, 27). The deep-rooted paternalism attached to it is therefore a kind of modern deviance, so there is little to prevent the imagining of traditions whose very unlikely existence has nevertheless been suggested: "At the storian [a chat, in Bislama], the chiefs recognized the importance of women in the community. A woman ... was telling chiefs that in Efate they should have women chiefs. Everyone went quiet. Someone was saying there were women chiefs before. I think the role of women will change for good. I don't know what change. I can imagine women being chief, it's already happened [key informant]" (AusAID 20I2, 28). 
In such contexts, it is not difficult to perceive that the problem of adapting custom to the most contemporary issues of postcolonial society or politics in Tanna or Vanuatu remains a pressing concern. In Tanna, noted Ron Brunton (1979), the role of chiefs with regard to social organization as it has been adapted throughout history is to guarantee the three aspects that characterize it: "Firstly there is an almost inflexible network of relations which prevents individuals or groups from creating or abandoning links as changing circumstances might otherwise dictate. Secondly, this network is all-encompassing; it does not just determine, for instance, the supply of a particular valuable or participation in a specific ritual. Thirdly, there is a system of titles which, although hierarchically conceived, is unable to mobilize sufficient power to constrain the autonomy of adult males.... The outcome is an atomistic society with a lot of structure" (Brunton 1979, IO2). And it is precisely because of this atomism that their kastom, all traditionalist rhetoric and modern political use of it aside, represents for the people of Tanna their guarantee of freedom and their collective independence as well as their individual autonomy. Traditional leaders' powerlessness to act outside their corporate group without the consent of other authorities, without a chain of command, is the glue holding together this Tannese representation of liberty within and through custom.

The power of custom, recalled Sahlins (I992, I999a), lies in its capacity to use modernity to its advantage. To this end, the kastom of Tanna makes it possible to distinguish two types of big men. Lindstrom thus identified among the island's traditional leaders those whose vocation is to assume a role of "local big man," whose authority stems from the composition of their corporate group, and those who show a natural ability to become "ideological big men," who are open to new possibilities and whose role it is to federate people beyond their local group (Lindstrom I98I). The latter's mobilizing action was above all embodied by big jifs during the missionaries' intransigent reign to enable them to gain new powers. It was later used by the leaders of the John Frum movement in an attempt to misappropriate white people's wealth, before being concentrated in the hands of the Nikoletan or TN chiefs to usher in development. Some of the alliances thus made in order to take control of destiny may have followed paths that were tortuous, sometimes worrying in the eyes of outside observers, but the strength of Tannese big men is their capacity to imagine the outcome. And as illustrated by the case of Chief Yaukalepwi and his cooperation with France, which led him to Jacques Chirac at the Quai 
Branly Museum, this faculty of imagination has proved just as fertile in recent years.

To use Sahlins's expression (I992, I999b), “the indigenization of modernity" has proved particularly inventive on Tanna during the last two centuries, even if the benefits, in terms of social and economic development, have been somewhat limited. The different figures of traditional or bureaucratic authority that have been raised to the big man level, depending on the demands of the local context and global situation, have been an essential part of this process. However, the modernization of traditions affecting the exercise of power through the codification of kastom, the attribution of neo-customary titles to foreigners, or the participation of chiefs in land-seizure operations, is proving to be an increasingly risky undertaking. It offers more and more possibilities for external bureaucratic and economic pressures to interfere in the internal affairs of Tannese society, to influence the way kastom may be reformed in the future. The threat in this is that the people of Tanna may be deprived of the right to manipulate their kastom themselves, may be prevented from following their own conception of a "develop-man" process, and may be thwarted from continuing their efforts to domesticate modernity for their own cultural benefit.

\section{Notes}

I This point in Sahlins 1992 stands in some significant contrast to his earlier work (Sahlins I963), which suggested the durability or stability of the concepts "chief" and "big man" for comparative anthropological purposes.

2 Article 7 a of the Malvatumauri constitution is a perfect mix of ethnological records, except for the dubious insistence on words like "legitimate" or "true": "Registration of chiefs. Sec.r: Legitimate chiefs must be of the line or blood of chiefs. Sec.2: A true chief must be recognized according to custom and there must be an installation ceremony. Sec.3: A chief must be publicly installed in a true custom ceremony in which pigs are killed and kava exchange" (Lindstrom and White I994, 234).

3 Orthographies used in Tanna's several languages are not standardized. Iermenu or ierumanu (Kwamera or South language) is also spelled iaramara or yeramara (Lenakel or West language) or iaramanang (Narak or Whitesands language); iani niko or yeni niko (Lenakel) is also spelled iani entete or ieni neteta (Kwamera).

4 Nakwiari (Kwamera) is also spelled nikouiar (Lenakel). 
5 What is surprising on the part of all those who expressed opinions on this matter of the Tannese customary name given to President Chirac is that they mention "tapunga" as a name or title. Tapunga, sometimes wrongly called "chiefs' kava," is a special root of Piper methysticum, grown above-ground in order to make its roots longer. It is decorated and used ritually during various ceremonies, generally as an honorific token between allied groups or as a reconciliatory gift.

6 Article 2 of the Twelve Nakamals' constitution states: "The real great nakamal of Tanna are: Ienamakel; Lahtapu; Enaprapen; Lounatimi; Iwel; Lamtehkal; Enauia; Ekukak; Envitana; Imarsa; Enmarae; Eneiae.”

\section{References}

Adams, Ron

I984 In the Land of Strangers: A Century of European Contact with

Tanna, I774-I874. Pacific Research Monograph 9. Canberra:

National Center for Development Studies, The Australian National

University.

Agence France-Presse. International news agency, Paris.

Akin, David

2004 Ancestral Vigilance and the Corrective Conscience: Kastom as Culture in a Melanesian Society. Anthropological Theory 4 (3): 299324 .

AusAID

2012 Vanuatu Kastom Governance Partnership: Case Study Report, September 20 Iо. Canberra: AusAID.

Babadzan, Alain

2004 Commentary: Kastom as Culture? Anthropological Theory 4 (3): $325-328$.

Balandier, Georges

I970 Political Anthropology. Translated by A M Sheridan Smith. London: Allen Lane.

Bolton, Lissant

I998 Chief Willie Bongmatur Maldo and the Role of Chiefs in Vanuatu. The Journal of Pacific History 33 (2): I79-195.

Bonnemaison, Joël

I987 Les fondements d'une identité: Territoire, histoire et société dans l'archipel de Vanuatu (Mélanésie). Volume 2: Tanna les hommeslieux. Paris: Office de la Recherche Scientifique et Technique d'OutreMer.

Brunton, Ron

I979 Kava and the Daily Dissolution of Society on Tanna, New Hebrides. Mankind I 2 (2): 93-IO3. 
Constitutional Committee

2009 Ripablik blong Vanuatu Epril/Septemba 1979. Port-Vila.

Crocombe, Ron

2007 Asia in the Pacific Islands: Replacing the West. Suva: Institute for Pacific Studies, the University of South Pacific.

D’Arcy, Adorina

I994 Tanna Island Kastom Law. Lenakel: Nikoletan.

Darmayan, Sara, and Régis Ghezelbash

2006 Plume secréte: A la recherche des paradis perdus de Tanna. Achère: Monde global éditions.

Geismar, Haidy, and Ralph Regenvanu

20I I Re-imagining the Economy in Vanuatu: An Interview with Ralph Regenvanu. In Made in Oceania: Social Movements, Cultural Heritage and the State in the Pacific, edited by Edvard Hviding and Knut Rio, 3 I-50. Wantage, uk: Sean Kingston Publishing.

Ghezelbash, Régis

2006 Plume. Documentary, 52 minutes, DVD. Paris: Fly Times Pictures/ Blue Bird Productions.

Gifford, Edward W

I929 Tongan Society. Honolulu: Bernice P Bishop Museum.

Government of the Republic of Vanuatu

I980 Constitution of the Republic of Vanuatu. https://web.archive.org/ web/20090430I 72 I00/http://vanuatugovernment.gov.vu/

Guiart, Jean government/library/constitution.html [accessed I7 April 20I8]

I956 Un siècle et demi de contacts culturels à Tanna. Paris: Publication de la Société des Océanistes 5.

Hours, Bernard

I978 Custom and Politics in the New Hebrides. Pacific Perspectives 8 (I): I 5-20.

Humphreys, Clarence B

1926 The Southern New Hebrides: An Ethnological Record. Cambridge, UK: Cambridge University Press.

Japan Times. Daily newspaper, Tokyo.

Keesing, Roger M, and Robert Tonkinson, editors

I982 Reinventing Traditional Culture: The Politics of Kastom in Island Melanesia. Special issue of Mankind I3 (4).

Lindstrom, Lamont

I98 I Achieving Wisdom: Knowledge and Politics on Tanna, Vanuatu. PhD dissertation, University of California-Berkeley.

I990 Big-Men as Ancestors: Inspiration and Copyrights on Tanna (Vanuatu). Ethnology 29 (4): 3 I3-326. 
I997 Chiefs in Vanuatu Today. In Chiefs Today: Traditional Pacific Leadership and the Colonial State, edited by Geoffrey White and Lamont Lindstrom, 2I I-228. Stanford: Stanford University Press.

Lindstrom, Lamont, and Geoffrey White

I993 Introduction: Custom Today. Anthropological Forum 6 (4): 465473 .

I997 Introduction. In Chiefs Today: Traditional Pacific Leadership and the Colonial State, edited by Geoffrey White and Lamont Lindstrom, I-I8. Stanford: Stanford University Press.

Lindstrom, Lamont, and Geoffrey White, editors

I994 Culture, Kastom, Tradition: Developing Cultural Policy in Melanesia. Suva: Institute of Pacific Studies, the University of South Pacific.

MacClancy, Jeremy

I980 To Kill a Bird with Two Stones: A Short History of Vanuatu. Port Vila: Vanuatu Cultural Centre.

I 988 Kastom and Politics. International Journal of Moral and Social Studies 3:95-IIO.

Miles, William F

I993 Traditional Rulers and Development Administration: Chieftaincy in Niger, Nigeria, and Vanuatu. Studies in Comparative International Development 28 (3): 3 I-50.

I998 Bridging Mental Boundaries in a Postcolonial Microcosm: Identity and Development in Vanuatu. Honolulu: University of Hawai'i Press.

Niko Letan

2006 Niko Letan Kanstituson. Lenakel: Nikoletan Council.

Nixon, Rod, Leisande Otto, and Raewyn Porter

$20 \mathrm{I}$ Wan Sip, Plante Kapten: Land Leasing on Tanna, Vanuatu. Justice for the Poor Research Report, May. Washington, DC: World Bank.

Otto, Ton, and Poul Pedersen

2005 Disentangling Traditions: Culture, Agency and Power. In Tradition and Agency: Tracing Cultural Continuity and Invention, edited by Ton Otto and Poul Pedersen, I I-50. Aarhus: University Press.

Pacnews. Regional news service, Suva.

Port Vila Presse. Weekly online newspaper.

Rodman, Margaret

I987 Masters of Tradition: Consequences of Customary Land Tenure in Longana, Vanuatu. Vancouver: University of British Columbia.

Sahlins, Marshall

I963 Poor Man, Rich Man, Big-Man, Chief: Political Types in Melanesia and Polynesia. Comparative Studies in Society and History 5 (3): $285-303$. 
1992 The Economics of Develop-Man in the Pacific. Res 2I:I 2-25.

I999a Two or Three Things that I Know about Culture. Journal of the Royal Anthropological Institute 5 (3): 399-42I.

I999b What Is Anthropological Enlightenment? Some Lessons of the Twentieth Century. Annual Review of Anthropology 28 (I): i-xxiii.

Sand, Christophe

2002 Melanesian Tribes vs. Polynesian Chiefdoms: Recent Archaeological Assessment of a Classic Model of Sociopolitical Types in Oceania. Asian Perspectives 4I (2): 284-296.

Spriggs, Matthew

2008 Ethnographic Parallels and the Denial of History. World Archaeology $40(4): 538-552$.

Tabani, Marc

2002 Les pouvoirs de la coutume à Vanuatu: Traditionalisme et édification nationale. Paris: L'Harmattan.

2008 Une pirogue pour le paradis: Le culte de John Frum à Tanna. Paris: Maison des Sciences de l'Homme.

Turner, George

I86I Nineteen Years in Polynesia: Missionary Life, Travels, and Researches in the Islands of the Pacific. London: J Snow.

Vanuatu Daily Post. Newspaper, Port Vila.

Vernaudon, Jacques, Tamatoa Bambridge, and Léonard D Sam

20I I Le vocabulaire politique contemporain dans les langues océaniennes, langues oceaniennes de Nouvelle-Caledonie et de Polynesie francaise. In Destin des collectivités politiques d'Océanie, volume I, Théories et pratiques, edited by Jean-Yves Faberon, V Fayoud, and Jean-Marc Regnault, I97-208. Paris: Éditions du CNRS.

Wilkinson, Julia F

I979 A Study of a Political and Religious Division on Tanna, New Hebrides. PhD dissertation, Cambridge University.

Woodward, Keith

2014 A Political Memoir of the Anglo-French Condominium of the New Hebrides. Canberra: ANU Press.

\section{Abstract}

Nearly twenty years after the publication of Chiefs Today: Traditional Pacific Leadership and the Colonial State, edited by Lamont Lindstrom and Geoffrey White (I997), this article extends and updates coverage of earlier discussions concerning local and national codifications of authority in the Pacific region and 
the relation of contemporary "chiefs" and other leaders with state bureaucracies. I address this topic through an analysis of the challenges faced in Vanuatu, since independence, by the attempt to design bureaucratic structures that build on indigenous systems of authority. Looking at the historical and contemporary situation of the Tannese society in the south of the archipelago, I observe the political history and transformation of chiefly status on Tanna, and how local actors in this island have manipulated leadership possibilities (and other aspects of local kastom), partly by drawing on outside resources and connections. This case study also connects with other issues including the ongoing transformation of the roles of local political leaders, global connections linking small Pacific Islands with metropolitan actors, and disputes over cultural property and cultural appropriation.

KEYWORDS: chiefs, kastom titles, local councils, state structures, Tanna island, Vanuatu 